\title{
Analog Search of Different Lateral Load Resisting System for High Rise Building
}

\author{
Tejas N. Kothari, Udaysingh Patil, Sharda P. Siddh
}

\begin{abstract}
As the rate of growth of population is increasing day by day, the requirement of land is increasing for different purposes. To accommodate this increased population, the height of building is increasing thereby subsequently increasing the importance of lateral load resisting system which provide adequate strength against lateral loading arising due to earthquake and wind. In present study various lateral load resisting system have been introduced which can resist the lateral forces and safely transfer them to soil thereby improving the strength and stiffness of column structures. The lateral load resisting systems that are widely used are conventional beam column system, shear wall system, tube system, outrigger system, tubular system etc. Diagrid structural system is generally adopted in tall buildings due to its structural efficiency and flexibility in planning. Compared to closely space vertical columns in Conventional Beam column system, diagrid structure consists of inclined columns on the exterior surface of building. The concrete diagrids member is used in both precast and cast in-situ type. An exhaustive study has been performed on the performance of 20 storey RCC building with plan size $18 \mathrm{~m} \times 18$ $m$ using $E-T A B$ software. All structural members are designed as per IS 456:2000 and all the load combinations of seismic forces are considered as per IS 1893(Part 1): 2002. Finally, Parameter such as storey displacement, storey stiffness and time period are compared and obtained results were presented in both graphically and tabular format.

Index Terms-Diagrid structural system, Shear wall system, Tube system, Beam Column System, High rise buildings, storey displacement, storey stiffness and Time period.
\end{abstract}

\section{INTRODUCTION}

Nowadays taller structures are preferred due to increase in population growth and limitation in availability of land therefore taller structures are better choice available now to avoid congestion. Construction of high rise structure is further complex without using any lateral load resisting system as it attracts large lateral forces arising may be due to earthquake and wind, thus this system makes the structure earthquake resistant by increasing strength and stiffness. This is in contrast with conventional structural system that resists gravitational loads. Many countries like Dubai, London, New York etc. are famous for construction of tall structures they are using lateral load resisting system to resist lateral forces subsequently increasing durability and reliability.
Lateral forces generated due to earthquake can cause larger stresses in structural elements, lateral sways or any other damaging effects which will lead to failure of structure thereby endangers the safety of individual. Thus to improve the seismic performance of building the provision of lateral

load resisting system is must. Thus in present study the emphasis is given to know the effectiveness of various systems available like shear wall system, tube system, outrigger system, tubular system etc. which can resist the force and safely transfer them to soil and to improve the strength and stiffness of column structures. Stiffness is directly proportional to deformation, larger is the stiffness larger is the force required to deform it. Increase in rigidity or stiffness at bottom of building decreases the top storey displacement and vice versa.

\section{BUILDING CONFIGURATION}

In present study model of 20 storey tall building, having $18 \mathrm{~m} \times 18 \mathrm{~m}$ plan dimension is developed using ETAB software with 4 types of lateral load resisting system i.e. conventional beam column system, shear wall system, tube system and diagrid system. In shear wall system, shear wall is at the center of structure in outer periphery. The tube system concept it as a building by designing it as a hollow cantilever perpendicular to ground, In diagrid structures, pair of braces is located on the periphery of the building. The angle of inclination of diagrid member is kept uniform throughout the height the structure. The inclined columns are provided at spacing of $3 \mathrm{~m}$ along the perimeter of structure. The interior structural frame of the diagrid structures is designed only for gravity load. The design dead load and live loads on floor slab are $2 \mathrm{kN} / \mathrm{m}^{2}$ and $1.5 \mathrm{kN} / \mathrm{m}^{2}$ respectively.

The design earthquake load is computed based on the zone factor of 0.36, medium soil, importance factor of 1 and response reduction factor of 5 (IS: 1893 (Part-I), 2002). Modeling, analysis and design of all the structure are carried out using ETABS software. All structural members are designed using IS 456:2000.

Revised Manuscript Received on July 10, 2019.

Tejas N. Kothari, M. Tech (Structural Engineering), Department of Civil Engineering, Shri Ramdeobaba College of Engineering and Management, Nagpur, Maharashtra, India. (tejasnk20395@gmail.com)

Udaysingh Patil, Assistant Professor, Department of Civil Engineering, Shri Ramdeobaba College of Engineering and Management, Nagpur, Maharashtra, India. (patil.udaysingh4@gmail.com)

Dr. Sharda P. Siddh, Assistant Professor, Department of Civil Engineering, Shri Ramdeobaba College of Engineering and Management, Nagpur, Maharashtra, India. (shardasiddh.9@gmail.com) 
A. Plan

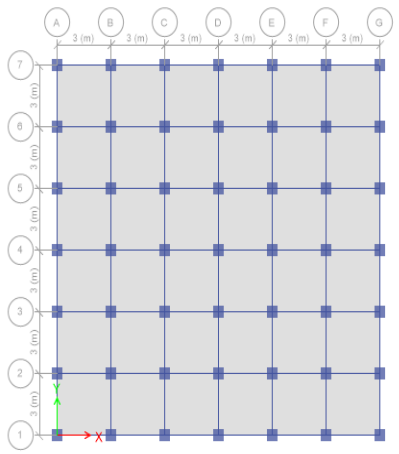

Figure 1: Beam Column System

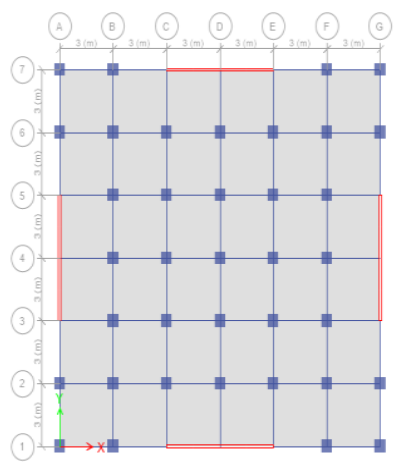

Figure 2: Shear Wall System

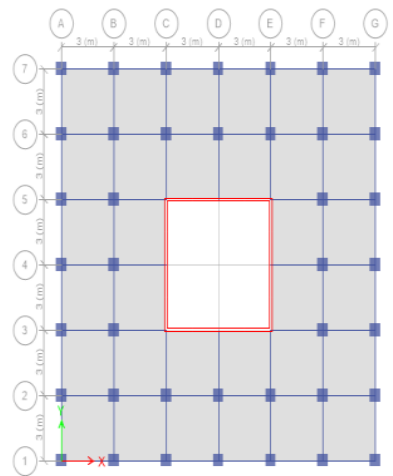

Figure 3: Frame Tube System

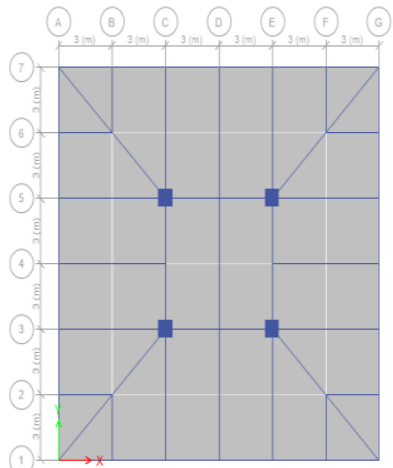

Figure 4: Diagrid System

B. Elevation

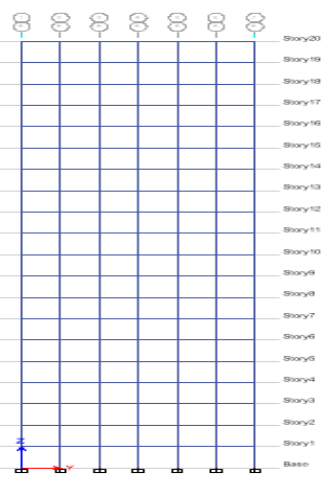

Figure 5: Beam Column System

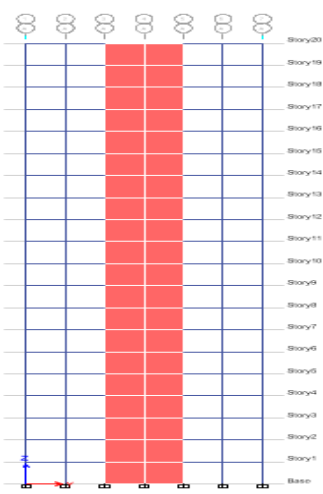

Figure 6: Shear Wall System

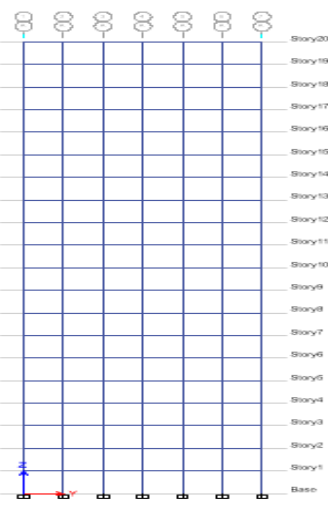

Figure 7: Frame Tube System

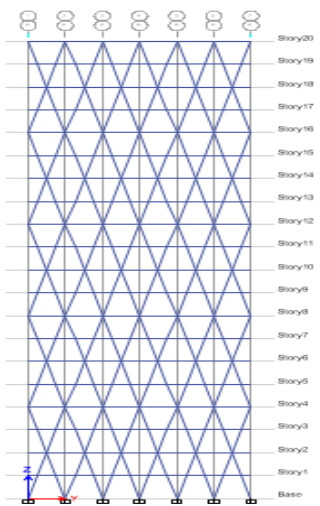

Figure 8: Diagrid System

Blue Eyes Intelligence Engineering

\& Sciences Publication 
C. 3D-Model

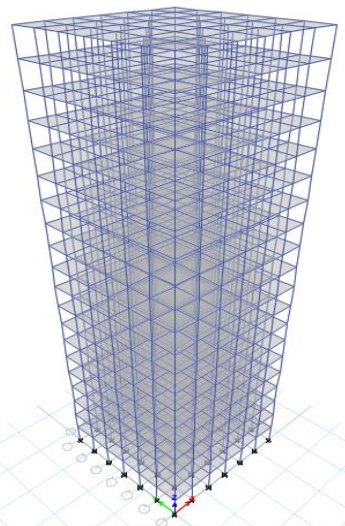

Figure 9: Beam Column System

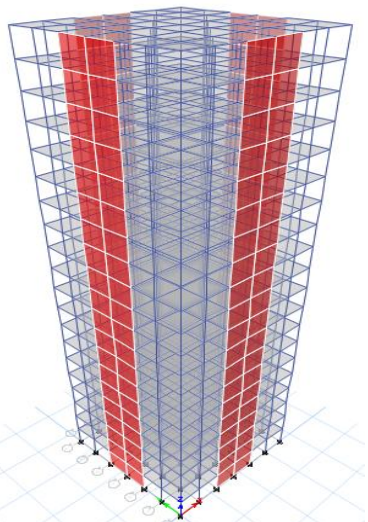

Figure 10: Shear Wall System

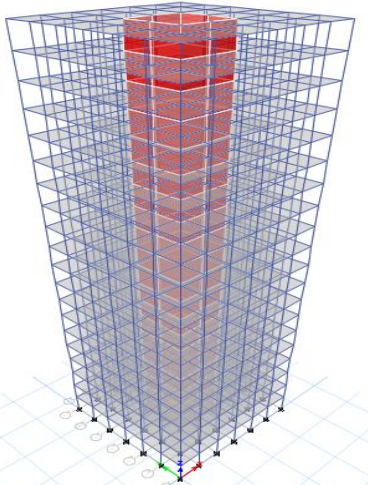

Figure 11: Frame Tube System

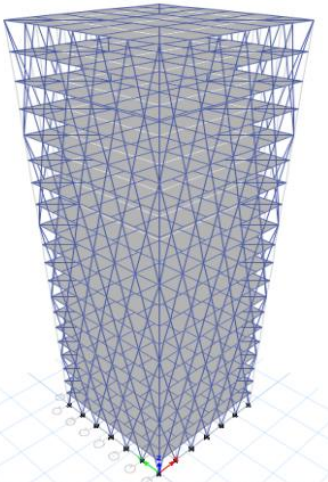

Figure 12: Diagrid System

Table 1:- Member sizes for all models (All Dimension in mm)

\begin{tabular}{|c|c|c|c|c|c|}
\hline $\begin{array}{c}\text { System } \\
\mathrm{s}\end{array}$ & Beam & $\begin{array}{c}\text { Colum } \\
\mathrm{n}\end{array}$ & $\begin{array}{c}\text { Diagr } \\
\text { id }\end{array}$ & $\begin{array}{c}\text { Slab } \\
\text { Thicknes } \\
\mathrm{s}\end{array}$ & $\begin{array}{c}\text { Shear } \\
\text { wall } \\
\text { Thick } \\
\text { ness }\end{array}$ \\
\hline $\begin{array}{c}\text { Beam } \\
\text { Colum } \\
\mathrm{n}\end{array}$ & $\begin{array}{c}450 \times 3 \\
00\end{array}$ & $\begin{array}{c}600 \times 60 \\
0\end{array}$ & - & 130 & - \\
\hline $\begin{array}{c}\text { Shear } \\
\text { Wall }\end{array}$ & $\begin{array}{c}450 \times 3 \\
00\end{array}$ & $\begin{array}{c}600 \times 60 \\
0\end{array}$ & - & 130 & 130 \\
\hline $\begin{array}{c}\text { Tube } \\
\text { System }\end{array}$ & $\begin{array}{c}450 \times 3 \\
00\end{array}$ & $\begin{array}{c}600 \times 60 \\
0\end{array}$ & - & 130 & 130 \\
\hline $\begin{array}{c}\text { B1- } \\
650 \times 4\end{array}$ & $\begin{array}{c}00 \mathrm{~B} 2- \\
500 \times 3\end{array}$ \\
$\begin{array}{c}\text { Diagrid } 33- \\
450 \times 3\end{array}$ & $00 \times 80$ \\
System & $500 \mathrm{x}$ & 500 & 130 & - \\
\hline
\end{tabular}

\section{RESULTS AND DISCUSSIONS}

The comparative analysis is carried out for Conventional structural system, Shear wall system, Tube system and diagrid structural system in terms of modal Time period, Storey Displacement and Storey Stiffness.

\section{A. Modal Time Period}

The time period for Conventional structure system, Shear wall system, Tube system and diagrid structure are shown in Fig. The first mode time period of Beam Column system is 2.027 seconds, for Shear wall system time period is 1.678 second, for Tube system time period is 1.494 second and for diagrid structural system time period is 1.089 . It can be seen that for conventional structural system the time period is more when compared with other lateral load system. The maximum reduction in time period is $53.72 \%$ compared to beam column system which will directly affect the displacement of structure.

Table 2:- Modal Time Period

\begin{tabular}{|c|c|c|c|c|}
\hline Mode & $\begin{array}{c}\text { Beam } \\
\text { Column } \\
\text { System }\end{array}$ & $\begin{array}{c}\text { Shear } \\
\text { Wall } \\
\text { System }\end{array}$ & $\begin{array}{c}\text { Tube } \\
\text { System }\end{array}$ & $\begin{array}{c}\text { Diagrid } \\
\text { System }\end{array}$ \\
\hline 1 & 2.027 & 1.678 & 1.494 & 1.089 \\
\hline 2 & 2.027 & 1.678 & 1.494 & 1.085 \\
\hline 3 & 1.837 & 1.228 & 1.151 & 0.568 \\
\hline 4 & 0.657 & 0.509 & 0.425 & 0.341 \\
\hline 5 & 0.657 & 0.509 & 0.425 & 0.34 \\
\hline 6 & 0.604 & 0.375 & 0.382 & 0.19 \\
\hline 7 & 0.371 & 0.264 & 0.227 & 0.185 \\
\hline 8 & 0.371 & 0.264 & 0.209 & 0.184 \\
\hline 9 & 0.353 & 0.196 & 0.209 & 0.13 \\
\hline 10 & 0.255 & 0.167 & 0.161 & 0.13 \\
\hline 11 & 0.255 & 0.167 & 0.132 & 0.115 \\
\hline 12 & 0.244 & 0.121 & 0.132 & 0.101 \\
\hline
\end{tabular}




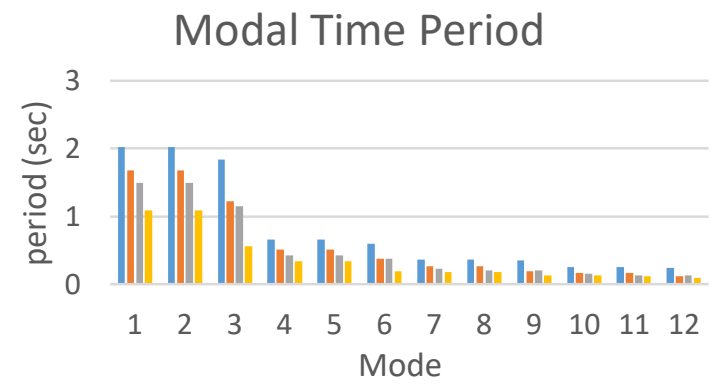

\section{Beam Column System $\quad$ Shear Wall System - Tube System Diagrid System}

Figure 13: Modal Time Period

\section{B. Storey Displacment}

Storey displacement for conventional structure system, shear wall system, tube system and diagrid structure is shown in Fig.14 It is observed that displacement for conventional structure due earthquake is higher compared to all lateral system. It can be observed that amongst 3 lateral systems, diagrid system shows less displacement.

The $20^{\text {th }}$ storey displacement of Beam Column system is $37.1 \mathrm{~mm}$, for Shear wall system storey displacement is 32.3 $\mathrm{mm}$, for Tube system storey displacement is $30.2 \mathrm{~mm}$ and for diagrid structural system storey displacement is 22.4 $\mathrm{mm}$.

Table 3:- Storey Displacement

\begin{tabular}{|l|r|r|r|r|}
\hline Storey & $\begin{array}{c}\text { Beam } \\
\text { Column } \\
\text { System }\end{array}$ & $\begin{array}{c}\text { Shear } \\
\text { Wall } \\
\text { System }\end{array}$ & $\begin{array}{c}\text { Tube } \\
\text { System }\end{array}$ & $\begin{array}{r}\text { Diagrid } \\
\text { System }\end{array}$ \\
\hline Storey1 & 0 & 0 & 0 & 0 \\
\hline Storey2 & 3.6 & 2 & 1.6 & 1.8 \\
\hline Storey3 & 6.2 & 3.8 & 2.9 & 3 \\
\hline Storey4 & 8.9 & 5.7 & 4.5 & 4.3 \\
\hline Storey5 & 11.4 & 7.8 & 6.1 & 5.6 \\
\hline Storey6 & 13.9 & 10 & 7.9 & 6.8 \\
\hline Storey7 & 16.4 & 12.1 & 9.7 & 8.1 \\
\hline Storey8 & 18.7 & 14.2 & 11.5 & 9.5 \\
\hline Storey9 & 20.9 & 16.2 & 13.4 & 10.7 \\
\hline Storey10 & 23 & 18.2 & 15.2 & 12 \\
\hline Storey11 & 25 & 20.1 & 17 & 13.3 \\
\hline Storey12 & 26.9 & 21.8 & 18.7 & 14.5 \\
\hline Storey13 & 28.7 & 23.5 & 20.4 & 15.7 \\
\hline Storey14 & 30.4 & 25.1 & 22 & 16.9 \\
\hline Storey15 & 31.9 & 26.6 & 23.6 & 18 \\
\hline Storey16 & 33.3 & 28 & 25.1 & 19 \\
\hline Storey17 & 34.5 & 29.2 & 26.5 & 20 \\
\hline Storey18 & 35.6 & 30.4 & 27.8 & 20.9 \\
\hline Storey19 & 36.4 & 31.4 & 29 & 21.7 \\
\hline Storey20 & 37.1 & 32.3 & 30.2 & 22.4 \\
\hline
\end{tabular}

Table 4:- Story Stiffness

\begin{tabular}{|c|c|c|c|c|}
\hline Story & $\begin{array}{c}\text { Beam } \\
\text { Column } \\
\text { System }\end{array}$ & $\begin{array}{c}\text { Shear } \\
\text { Wall } \\
\text { System }\end{array}$ & $\begin{array}{c}\text { Tube } \\
\text { System }\end{array}$ & $\begin{array}{l}\text { Diagrid } \\
\text { System }\end{array}$ \\
\hline $\begin{array}{l}\text { Story2 } \\
0\end{array}$ & $\begin{array}{r}373452.3 \\
4\end{array}$ & $\begin{array}{r}335514 . \\
1\end{array}$ & $\begin{array}{r}318790 . \\
1\end{array}$ & 526656.3 \\
\hline $\begin{array}{l}\text { Story1 } \\
9\end{array}$ & $\begin{array}{r}571710.0 \\
2\end{array}$ & $\begin{array}{r}581916 . \\
8\end{array}$ & $\begin{array}{r}573648 . \\
5\end{array}$ & 908241.2 \\
\hline $\begin{array}{l}\text { Story1 } \\
8\end{array}$ & $\begin{array}{r}652646.7 \\
3\end{array}$ & $\begin{array}{r}724678 . \\
6\end{array}$ & 746805 & 1235631 \\
\hline $\begin{array}{l}\text { Story1 } \\
7\end{array}$ & $\begin{array}{r}690190.1 \\
7\end{array}$ & $\begin{array}{r}799803 . \\
5\end{array}$ & $\begin{array}{r}855545 . \\
3\end{array}$ & 1393332 \\
\hline $\begin{array}{l}\text { Story1 } \\
6\end{array}$ & $\begin{array}{r}710463.1 \\
5\end{array}$ & $\begin{array}{r}839979 . \\
3\end{array}$ & $\begin{array}{r}924587 . \\
2\end{array}$ & 1589717 \\
\hline $\begin{array}{l}\text { Story1 } \\
5\end{array}$ & $\begin{array}{r}724043.2 \\
3\end{array}$ & $\begin{array}{r}863466 . \\
7\end{array}$ & $\begin{array}{r}971588 . \\
6\end{array}$ & 1672432 \\
\hline $\begin{array}{l}\text { Story1 } \\
4\end{array}$ & $\begin{array}{r}735148.4 \\
8\end{array}$ & $\begin{array}{r}878977 . \\
7\end{array}$ & $\begin{array}{r}100727 \\
7\end{array}$ & 1814122 \\
\hline $\begin{array}{l}\text { Story1 } \\
3\end{array}$ & $\begin{array}{r}745100.6 \\
4\end{array}$ & $\begin{array}{r}890302 . \\
3\end{array}$ & $\begin{array}{r}103769 \\
7\end{array}$ & 1872799 \\
\hline $\begin{array}{l}\text { Story1 } \\
2\end{array}$ & 754435.4 & $\begin{array}{r}900141 . \\
1\end{array}$ & $\begin{array}{r}106742 \\
6\end{array}$ & 1958290 \\
\hline $\begin{array}{l}\text { Story1 } \\
1\end{array}$ & 763985.8 & $\begin{array}{r}911686 . \\
5\end{array}$ & $\begin{array}{r}110133 \\
2\end{array}$ & 2026878 \\
\hline $\begin{array}{l}\text { Story1 } \\
0\end{array}$ & $\begin{array}{r}774738.6 \\
9 \\
\end{array}$ & $\begin{array}{r}927992 . \\
6\end{array}$ & $\begin{array}{r}114419 \\
2 \\
\end{array}$ & 2180544 \\
\hline Story9 & 787110.5 & $\begin{array}{r}950846 . \\
6\end{array}$ & $\begin{array}{r}119962 \\
0\end{array}$ & 2260647 \\
\hline
\end{tabular}

\section{Figure 14: Storey Displacement}

\section{Storey Stiffness}

The distribution of story Stiffness along the height for Beam Column System, Shear wall system, Tube system and diagrid structure due earthquake is shown in Fig.15. The stability of RCC-structure increases with increase in stiffness of column. It is observed that story stiffness for diagrid structure due to earthquake load is higher compared to conventional structure, shear wall system and tube system. Since stiffness is directly proportional to displacement. Due to increase in stiffness diagrid structures shows less displacement as given in table 3 . 


\begin{tabular}{|l|r|r|r|l|}
\hline Story8 & 800728.9 & 981080. & 127031 & \multirow{2}{*}{2310742} \\
\hline Story7 & 815073.1 & 5 & 6 & \\
\hline Story6 & 830266.3 & 107386 & 147692 & \multirow{2}{*}{2675213} \\
\hline Story5 & 847496.7 & 115102 & 163528 & \multirow{2}{*}{2820932} \\
\hline Story4 & 870313.8 & 127111 & 186290 & \multirow{2}{*}{2828528} \\
\hline Story3 & 912211.6 & 148325 & 221961 & \multirow{2}{*}{2981627} \\
\hline Story2 & $\begin{array}{r}1039164 . \\
2\end{array}$ & 193000 & 288187 & \multirow{2}{*}{3366003} \\
\hline Story1 & $\begin{array}{r}1927283 . \\
8\end{array}$ & 395261 & 510367 & \multirow{2}{*}{5694295} \\
\hline
\end{tabular}

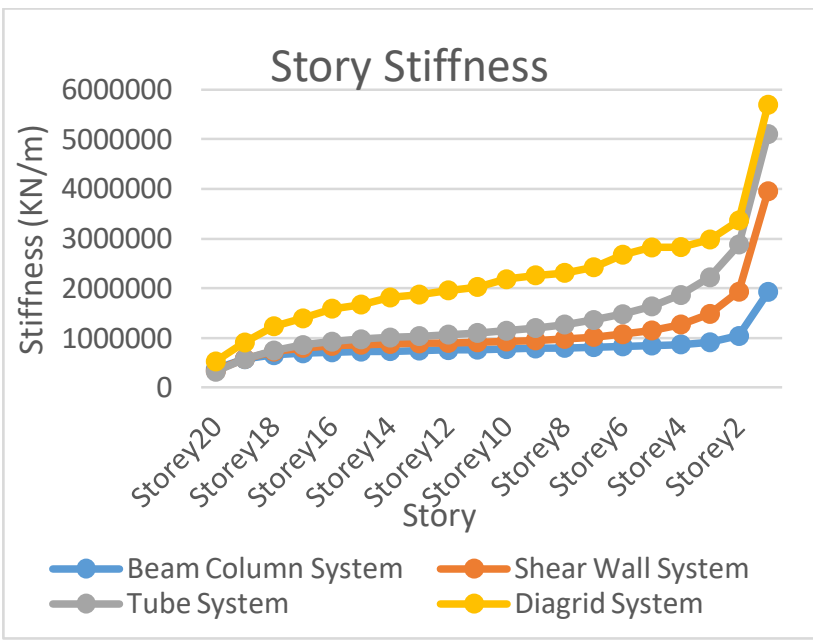

Figure 15: Story Stiffness

\section{CONCLUSION}

In this paper, comparative analysis and design of 20storey diagrid structural system building, shear wall system, tube system and simple frame building is presented. A Regular symmetrical plan of $18 \mathrm{~m} \times 18 \mathrm{~m}$ size is considered. of structure. Analysis results like story displacement, story stiffness and modal time period are presented here. Also design of all the structures is done and optimum member sizes are decided to satisfy the code criteria. From the detail analysis following conclusions can be drawn.

a. Top story displacement is much less in diagrid structure compared to other lateral system therefore it is much effective in resisting lateral loads.

b. Diagrid provides more resistance to lateral loads in the building which makes system more effective. Also weight of diagrid structure is more due to which base shear increases but eventually gives better performance under seismic loading.

c. The stability of structure increases with increase in stiffness of column. As the stiffness of column increases, displacement of structure decreases.

d. The design of both structures are done by using same member size but that member sizes are not fulfilling the design criteria in case of simple frame structure and failure occurs with excessive top story ETABS software is used for modelling, analysis and design

displacement. So the higher member size are used to prevent the criteria of failure and satisfy IS provisions.

e. It can be concluded that stiffness of diagrid system is more compared to beam column, shear wall and tube system. Due to increase in stiffness, story displacement and modal time period are reduced, that means damping of structure is increased, i.e., stresses induced due to displacement is reduced.

f. Diagrid structure system provides more economy in terms of consumption of steel and concrete as compared to simple frame building.

g. Diagrid structural system provides more flexibility in planning interior space and façade of the building

\section{REFERENCES}

1. Kyoung-sun Moon, Jerome J. Conner, John E. Fernandez, "Diagrid structural system for tall buildings: characteristics and methodology for preliminary design". The Structura Design of Tall and Special Building, 2007, Page no. 205-230.

2. Elena Mele, Maurizio Toreno, "Diagrid structure for tall buildings: case studies and design considerations". The Structural Design of Tall and Special Buildings, 2014, Page no. $124-145$.

3. G. M. Montuori, Elena Mele, "Secondary Bracing Systems for diagrid Structures in tall building". Structural Engineering, 2014.

4. Nilesh M. Gautami, Sumant B. Patel, "Comparison of various structural systems for tall steel buildings in Indian scenario". Journal of Information, Knowledge and Research in Civil Engineering, 2012, Page no. 78 - 82.

5. Harish Varsani, Dipesh Gandhi, "Comparative Analysis of diagrid structural system and conventional structural system for high rise steel building". International Journal of Advance Research in Engineering, Science \& Technology, January2015.

6. Khushbu Jani, Paresh V. Patel, "Analysis and design of diagrid structural system for high rise steel buildings". ELSEVIER, 2013, Page no. 92- 100.

7. Nishith B. Panchal, V. R. Patel, "Optimum angle of diagrid structural system". International Journal of Engineering and Technical Research, June- 2014.

8. IS 875 (part-3) - 1987. "Code of practice for design loads (other than earthquake) for building and structures, wind load". Bureau of Indian Standard, New Delhi.

9. G. M. Montuori, Elena Mele, "Geometrical pattern for diagrid buildings: Exploring alternative design strategies from the structural point of view". Engineering Structures, 2014.

10. J. Kim, Y. Jun, "Seismic Performance Evaluation of Diagrid System Buildings", $2^{\text {nd }}$ Specialty Conference on Disaster Mitigation, Manitoba, June 2010.

11. Pallavi Bhale, P. Salunke, "Analytical study and design of diagrid building and comparison with conventional frame building", International Journal of Advanced Technology in Engineering and Science, Vol. No. 4, Issue No. 01, 2016.

12. IS: 875(Part-I, II, III)-1987, Code of Practice for Design Loads (other than Earthquake) for Buildings and Structures,

13. IS: 1893(Part-I)-2002, Criteria for Earthquake Resistant Design of Structures, Bureau of Indian Standard, New Delhi.

14. IS: 456-2000. Plain and Reinforced Concrete- Code of Practice (Fourth Revision), Bureau of Indian Standard, New Delhi.

15. Bureau of Indian Standard, New Delhi. 